Erratum

\title{
Erratum: Lazar-Karsten, P., et al. Generation and Characterization of Vascular Smooth Muscle Cell Lines Derived from a Patient with a Bicuspid Aortic Valve. Cells 2016, 5, 19
}

\author{
Pamela Lazar-Karsten ${ }^{1,+}$, Gazanfer Belge ${ }^{2,+}$, Detlev Schult-Badusche ${ }^{1}$, Tim Focken ${ }^{2}$, \\ Arlo Radtke ${ }^{2}$, Junfeng Yan ${ }^{1}$, Pramod Ranabhat ${ }^{1}$ and Salah A. Mohamed ${ }^{1, *}$ \\ 1 Department of Cardiac and Thoracic Vascular Surgery, University of Luebeck, D-23538 Luebeck, Germany; \\ pamela.lazar-karsten@uksh.de (P.L.-K.); detlev.schult-badusche@uksh.de (D.S.-B.); \\ junfeng.yan@uksh.de (J.Y.); pramod.ranabhat@student.uni-luebeck.de (P.R.) \\ 2 Center of Human Genetics and Genetic Counselling, University of Bremen, D-28359 Bremen, Germany; \\ belge@uni-bremen.de (G.B.); focken@uni-bremen.de (T.F.); arlo.radtke@gmx.de (A.R.) \\ * Correspondence: salah.mohamed@uksh.de; Tel.: +49-451-500-6425; Fax: +49-451-500-2051 \\ + These authors contributed equally to this work.
}

Academic Editor: Alexander E. Kalyuzhny

Received: 1 September 2016; Accepted: 8 September 2016; Published: 20 September 2016

The authors wish to make the following erratum to this paper [1]. The author's name "Pramod Renhabat" should be "Pramod Ranabhat".

We apologize for any inconvenience caused to the readers.

\section{Reference}

1. Lazar-Karsten, P.; Belge, G.; Schult-Badusche, D.; Focken, T.; Radtke, A.; Yan, J.; Renhabat, P.; Mohamed, S.A. Generation and Characterization of Vascular Smooth Muscle Cell Lines Derived from a Patient with a Bicuspid Aortic Valve. Cells 2016, 5, 19. [CrossRef] [PubMed]

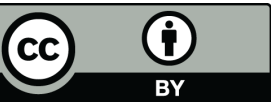

(C) 2016 by the authors; licensee MDPI, Basel, Switzerland. This article is an open access article distributed under the terms and conditions of the Creative Commons Attribution (CC-BY) license (http://creativecommons.org/licenses/by/4.0/). 